\title{
Bank Deregulation, Asset Concentration And Safety \& Soundness Of Banking Industry
}

Dan Zhou, California State University at Bakersfield, USA

Ken Shakoori, Brandman University, Irvine-California, USA

\begin{abstract}
In this paper, we examine the pattern of asset concentration among 900 largest bank holding companies in the United States during 1986-2008. The entropy coefficient is used as a measure of concentration because it is said to be theoretically sound and superior to other models due to its decomposition properties (Theil, 1972). Decomposing 900 bank holding companies in nine 100subgroups and testing the within-set and between-set concentration of total assets and selected groups of individual assets revealed that the bottom 850 bank holding companies did not exhibit a noticeable change in asset concentration. However, a significant concentration of assets took place among the top 50 bank holding companies. The result of this study, in light of the recent financial turmoil that showed the largest bank holding companies' (i.e., Bank of America, Citicorp, etc.) systematic risk exceeded their ability to remain solvent, has significant policy implication (i.e., bail out the largest bank under the too-big to-fail doctrine).
\end{abstract}

Keywords: bank holding companies; total asset concentration; individual asset; systematic risk

\section{INTRODUCTION}

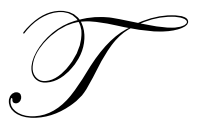

he Congressional Oversight Panel's 2009 Special Report on Regulatory Reform states that "financial crises are not new. As early as 1792, during the presidency of George Washington, the nation suffered a severe panic that froze credit and nearly brought the young economy to its knees. Over the next 140 years, financial crises struck on a regular basis - in 1797, 1819, 1837, 1857, 1873, 1893-96, 1907, and 1929-33 - roughly every 15 to 20 years." However, to avoid systematic risk as a prime objective, new financial regulation - including federal deposit insurance, securities regulation, and banking supervision - effectively protected the system from devastating financial crisis for more than 50 years. The safety and soundness of the financial system changed the attitude of financial firms and policy makers to see regulation as an impediment to efficient functioning of the capital markets. As a result, this attitude change led to the enactment of the Depository Institutions Deregulation and Monetary Control Act of 1980 - the most important federal legislation relating to the financial community since the 1930s, followed by several other banking acts between 1982 and 1999, such as the Riegle-Neal Interstate Banking and Branching Efficiency Act of 1994. These legislations encouraged consolidation of bank holding companies causing a substantial concentration of assets. Stiroh and Poole (2000) found that the rise in the concentration of assets among the 50 largest United States bank holding companies in the 1990s was almost entirely due to external growth through mergers and acquisitions.

In this paper, we use the entropy coefficient as a measure of concentration to examine the asset concentration pattern among 900 largest bank holding companies (BHCs) in the United States during 1986-2008. While there is wide array of concentration measures proposed in the industrial organization literature, the review of banking literature reveals that the k-firm concentration ratio and Herfindahl-Hirschman index (HHI) are predominately used to measure bank asset concentration (Yeyati and Micco, 2007). The use of the entropy coefficient as a measure of concentration is said to be theoretically sound and superior to other models due to its decomposition properties (Theil, 1972). Applying this methodology to the U.S. BHCs, we examine the pattern of 
total assets concentration among the upper and lower tier BHCs from 1986 to 2008 (i.e., during and after regulatory reform of the 1980s). Furthermore, to examine the risk-taking behavior of BHCs, we also study the concentration patterns of selected groups of individual assets over the same time period.

By decomposing 900 BHCs in nine 100-subgroups and testing within-set and between-set concentrations of total assets and selected groups of individual assets, we find that the largest 50 bank holding companies had significant increases in asset concentration, while the remaining 850 bank holding companies did not exhibit a noticeable change of asset concentration.

\section{METHODOLOGY}

Ludwig Boltzmann (1877) has been credited for developing the entropy concept. Claude Shannon (1948) introduced probabilistic interpretation of entropy in information theory and Henry Theil, in his two books Economics and Information Theory (1967) and Statistical Decomposition Analysis (1972), developed some economics applications in relation to information theory. Entropy coefficient as a measure of concentration or diversity, is one of those economic applications that is said to be superior to other models due to its decomposition properties (Theil, 1972, and Attaran \& Zwick, 1987).

The entropy measure of concentration $(\mathrm{C})$ is defined as:

$C\left(A_{1}, A_{2}, \cdots, A_{n}\right)=-\sum_{i=1}^{n} A_{i} \log _{2} A_{i}$

where $n$ is the number of BHCs and $A_{i}, i=1, \cdots, n$ is the $i$ th firm's assets relative to the sum of all BHCs' assets, so $\sum_{i=1}^{n} A_{i}=1$. The base of the logarithm is arbitrary and we chose two as the base $1^{1}$. The entropy coefficient is an inverse measure of concentration: a lower coefficient of $C$ indicates that smaller number of BHCs own most of the assets. For example, $C_{\min }=0$ represents a case of one BHC owing $100 \%$ of all assets. The highest coefficient of concentration is given by $C_{\max }=\log _{2}(n)$ and stands for all BHCs owning an equal amount of assets. Therefore, the concentration coefficient lies between $0=C_{\min } \leq C \leq C_{\max }=\log _{2}(n)$.

One of the properties of the entropy is that it could be decomposed or disaggregated into between-set and within-set entropies (Theil, 1972). This disaggregation property is very useful when data are available for number of BHCs by size of their assets. In this study, we divide BHCs into subgroups $\left(S_{g},(g=1, \ldots, G)\right)$ and monitor their asset concentration patterns over time and compare them with other subgroups. $S_{1}$ is the top group of bank holding companies owing the largest levels of assets and $S_{G}$ is the bottom group of bank holding companies owing the lowest levels of assets. The proportion of each subgroup of BHCs' assets to the total BHCs' assets is given by:

$$
A_{g}=\sum_{i \varepsilon \mathrm{S}_{\mathrm{g}}} A_{i} \quad \mathrm{~g}=1, \ldots, \mathrm{G}
$$

\footnotetext{
${ }^{1}$ When use at two, the measurement unit of entropy is known as BIT, binary digit.
} 
The within-set entropy $C_{\text {within } \mathrm{s}}$ is defined by Equation (2). The entropy coefficient of concentration within a particular subgroup, $S_{g}$, can be expressed by:

$$
C_{\text {within } \mathrm{g}}=-\sum_{i \varepsilon \mathrm{S}_{\mathrm{g}}}\left(A_{i} / A_{g}\right) \log _{2}\left(A_{i} / A_{g}\right)
$$

When the total number of BHCs is divided into subgroups, each subgroup would analytically have its own concentration coefficient. Weighting Equation (2) by $A_{g} / A_{S}$ yields into the relative share of each subgroup to the total entropy, where $A_{S}=\sum_{i=1}^{G} A_{i}$. The total within-set entropy coefficient is given by Equation (3)

$$
C_{\text {within }}=\sum_{g=1}^{G}\left(A_{g} / A_{s}\right)\left[-\sum_{i \varepsilon S_{g}}\left(A_{i} / A_{g}\right) \log _{2}\left(A_{i} / A_{g}\right)\right]
$$

Between-set entropy is defined by Equation (4).

$$
C_{\text {between }}=-\sum_{g=1}^{G}\left(A_{g} / A_{s}\right) \log _{2}\left(A_{g} / A_{s}\right)
$$

The summation of Equation (3) and Equation (4) is the overall entropy measure of all BHCs.

$$
E(C)=-\sum_{g=1}^{G}\left(A_{g} / A_{s}\right) \log _{2}\left(A_{g} / A_{s}\right)+\sum_{g=1}^{G}\left(A_{g} / A_{s}\right)\left[-\sum_{i \varepsilon \mathrm{S}_{\mathrm{g}}}\left(A_{i} / A_{g}\right) \log _{2}\left(A_{i} / A_{g}\right)\right]
$$

\section{SOURCE OF BANK HOLDING COMPANY DATA}

We obtained financial data of BHCs from the Federal Reserve Bank of Chicago from the second quarter of 1986 through the third quarter of 2008. Table 1 depicts data used in this study ${ }^{2}$.

\section{RESULTS}

We selected the top 900 BHCs for our study due to their consistency and reliability. To determine the pattern of the BHCs asset concentrations, we divided these 900 BHCs into nine subgroups, with each containing 100 BHCs ranked by their asset size. After careful examination of the raw data, we decided to divide the first top 100 BHCs into two subgroups of 50 BHCs as well. Using Equation (1) through Equation (5), we analyzed the entropy coefficients of total assets for the 900 BHCs and each subgroup. The result is presented in Table 2.

The total assets of the top 900 BHCs (Table 2, Column 12) demonstrate a slight trend toward diversification between 1986-1990 (7.27 - 7.59) and thereafter, a trend change toward concentration (7.59 - 5.21). Clearly, BHCs were responding to the banking deregulations of 1980 through 1999. Please note that the 900 BHCs entropy coefficients would range from a minimum of zero to a maximum value of $C=\log _{2} 900=9.81$. The maximum value is used to calculate the concentration index where the higher value indicates lower concentration. The asset concentration index is calculated by dividing entropy coefficient by the maximum value. Obviously, since

\footnotetext{
${ }^{2}$ Source: http://www.chicagofed.org/economic_research_and_data/bhc_data.cfm
} 
1990, the BHCs have shown a remarkable degree of the total assets concentration increasing, which is indicated by the assets concentration index decreasing from 74\% (7.27/9.81) in 1986 to 53\% (5.21/9.81) in 2008.

Keeping each subgroup independent and applying Equation (3), the within-set entropy coefficient of each subgroup is calculated and presented in Table 2, Columns 1-9. Since each subgroup consists of 100 BHCs, the entropy coefficients should range from a minimum of zero and a maximum value of $C=\log _{2} 100=6.64$. Column 1 is the result of the first top 100 BHCs total assets entropy coefficients and exhibits the same pattern of changes that occurred in all 900 BHCs total assets reported earlier. Entropy coefficients dropped from 5.87 (88\%) in 1986 to 4.49 (67\%) in 2008, signifying the concentration of total assets among the first top 100 BHCs increased. However, remaining subgroups (second top 100 through bottom 100) did not exhibit any significant increase in total assets concentration (Figure 1). In fact, the $t$-statistics indicate slight diversification did take place in some subgroups during 1986 - 2008.

Table 1: Item Definition Of Data Used In This Study

\begin{tabular}{|c|c|c|}
\hline & $\begin{array}{c}\text { Database } \\
\text { Item } \\
\text { Number }\end{array}$ & Item Definition \\
\hline Total Assets & BHCK2170 & Total Assets \\
\hline \multirow{4}{*}{ Asset I } & BHCK0081 & Noninterest-bearing balances and currency and coin \\
\hline & BHCK0395 & Interest-bearing balances in U.S. offices \\
\hline & BHCK0397 & Interest-bearing balances in foreign offices, edge and agreement subsidiaries and IBFs \\
\hline & BHCK1350 & $\begin{array}{l}\text { Federal funds sold and securities purchased under agreements to resell in domestic offices of } \\
\text { the bank and of its edge and agreement subsidiaries, and in IBFs }\end{array}$ \\
\hline Asset II & BHCK2122 & Total loans and leases, net of unearned income \\
\hline \multirow{2}{*}{ Asset III } & BHCK2145 & Premises and fixed assets (including capitalized leases) \\
\hline & BHCK2150 & Other real estate owned \\
\hline \multirow{2}{*}{ Asset IV } & BHCK2130 & Investments and unconsolidated subsidiaries and associated companies \\
\hline & BHCK2155 & Customers' liability to this bank on acceptances outstanding \\
\hline Asset V & BHCK3164 & Mortgage servicing assets \\
\hline \multirow{2}{*}{ Asset VI } & BHCK3163 & Goodwill \\
\hline & BHCK2160 & Other assets \\
\hline \multirow{4}{*}{$\begin{array}{c}\text { SWAP } \\
\text { Instruments }\end{array}$} & BHCK3450 & Interest rate contracts - notional value of all outstanding interest rate swaps \\
\hline & BHCK3826 & Foreign exchange swaps \\
\hline & BHCK8719 & Equity swaps \\
\hline & BHCK8720 & Commodity and other swaps \\
\hline
\end{tabular}

The result of the between-set entropy coefficients is given in Column 11 of Table 2. The between-set figures indicate the extent to which the total assets of 900 BHCs are distributed among nine subgroups with each containing 100 BHCs. The entropy coefficient of 1.24 in 1986 declined to 0.56 in 2008, indicating a trend toward a greater between-set concentration ${ }^{3}$.

The result of the entropy coefficients clearly confirmed our observation of the raw data indicating that most of the asset concentration took place among the first top 100 BHCs. Given this observation, we further divided the first top 100 BHCs into subgroups of the top 50 and the bottom 50.

\footnotetext{
${ }^{3}$ Since there are 9 subgroups, entropy coefficients would range from a minimum of zero to a maximum value of $C=\log _{2} 9=3.17$.
} 
Journal of Business \& Economics Research - July 2011

Volume 9, Number 7

\begin{tabular}{|c|c|c|c|c|c|c|c|c|c|c|c|c|}
\hline Quarter & $\begin{array}{c}(1) \\
\text { Within } \\
\text { Set } \\
1^{\text {st }} \text { Top } \\
\text { 100 } \\
\end{array}$ & $\begin{array}{c}(2) \\
\text { Within } \\
\text { Set } \\
2^{\text {nd }} \text { Top } \\
\text { 100 } \\
\end{array}$ & $\begin{array}{c}(3) \\
\text { Within } \\
\text { Set } \\
3^{\text {rd }} \text { Top } \\
100 \\
\end{array}$ & $\begin{array}{c}(4) \\
\text { Within } \\
\text { Set } \\
4^{\text {th }} \text { Top } \\
100 \\
\end{array}$ & $\begin{array}{c}\text { (5) } \\
\text { Within } \\
\text { Set } \\
5^{\text {th }} \text { Top } \\
100 \\
\end{array}$ & $\begin{array}{c}(6) \\
\text { Within } \\
\text { Set } \\
\text { 6 }^{\text {th }} \text { Top } \\
100 \\
\end{array}$ & $\begin{array}{c}(7) \\
\text { Within } \\
\text { Set } \\
7^{\text {th }} \text { Top } \\
\text { 100 } \\
\end{array}$ & $\begin{array}{c}(8) \\
\text { Within } \\
\text { Set } \\
8^{\text {th }} \text { Top } \\
100 \\
\end{array}$ & $\begin{array}{c}(9) \\
\text { Within } \\
\text { Set } \\
\text { Bottom } \\
\text { 100 } \\
\end{array}$ & $\begin{array}{c}(10) \\
\text { Total } \\
\text { Weighted } \\
\text { Within } \\
\text { Set } \\
\end{array}$ & $\begin{array}{c}\text { (11) } \\
\text { Between } \\
\text { Sets }\end{array}$ & $\begin{array}{l}\text { (12) } \\
\text { Total }\end{array}$ \\
\hline 1986 Q3 & 5.8715 & 6.5708 & 6.6134 & 6.6262 & 6.6383 & 6.6403 & 6.6418 & 6.6425 & 6.6406 & 6.0281 & 1.2441 & 7.2723 \\
\hline 1987 Q3 & 5.8702 & 6.5739 & 6.6142 & 6.6276 & 6.6382 & 6.6402 & 6.6420 & 6.6424 & 6.6422 & 6.0154 & 1.1779 & 7.1933 \\
\hline 1988 Q3 & 5.8965 & 6.5766 & 6.6129 & 6.6342 & 6.6373 & 6.6401 & 6.6426 & 6.6425 & 6.6424 & 6.0352 & 1.1757 & 7.2108 \\
\hline 1989 Q3 & 5.8930 & 6.5757 & 6.6155 & 6.6337 & 6.6379 & 6.6399 & 6.6424 & 6.6424 & 6.6426 & 6.0279 & 1.1495 & 7.1775 \\
\hline 1990 Q3 & 6.1079 & 6.5761 & 6.6095 & 6.6142 & 6.6371 & 6.6372 & 6.6409 & 6.6424 & 6.6420 & 6.2309 & 1.3618 & 7.5927 \\
\hline 1991 Q3 & 6.0758 & 6.5735 & 6.6069 & 6.6147 & 6.6351 & 6.6396 & 6.6412 & 6.6417 & 6.6426 & 6.2027 & 1.3397 & 7.5423 \\
\hline 1992 Q3 & 5.9350 & 6.5803 & 6.6053 & 6.6205 & 6.6330 & 6.6415 & 6.6413 & 6.6418 & 6.6427 & 6.0869 & 1.2851 & 7.3720 \\
\hline 1993 Q3 & 5.9541 & 6.5582 & 6.6141 & 6.6274 & 6.6361 & 6.6412 & 6.6418 & 6.6423 & 6.6429 & 6.0825 & 1.1734 & 7.2560 \\
\hline 1994 Q3 & 5.8530 & 6.5457 & 6.6161 & 6.6250 & 6.6372 & 6.6397 & 6.6418 & 6.6425 & 6.6431 & 5.9892 & 1.1050 & 7.0942 \\
\hline 1995 Q3 & 5.8516 & 6.5590 & 6.6145 & 6.6259 & 6.6372 & 6.6395 & 6.6419 & 6.6422 & 6.6429 & 5.9887 & 1.1031 & 7.0919 \\
\hline 1996 Q3 & 5.7149 & 6.5744 & 6.6120 & 6.6338 & 6.6394 & 6.6405 & 6.6412 & 6.6426 & 6.6428 & 5.8609 & 1.0239 & 6.8848 \\
\hline 1997 Q3 & 5.6542 & 6.5611 & 6.6150 & 6.6284 & 6.6408 & 6.6397 & 6.6417 & 6.6425 & 6.6429 & 5.7949 & 0.9574 & 6.7523 \\
\hline 1998 Q3 & 5.5409 & 6.5409 & 6.6202 & 6.6325 & 6.6393 & 6.6415 & 6.6418 & 6.6426 & 6.6430 & 5.6861 & 0.9116 & 6.5977 \\
\hline 1999 Q3 & 5.3875 & 6.5525 & 6.6176 & 6.6341 & 6.6395 & 6.6413 & 6.6415 & 6.6427 & 6.6427 & 5.5341 & 0.8225 & 6.3567 \\
\hline $2000 \mathrm{Q} 3$ & 5.3686 & 6.5460 & 6.6159 & 6.6354 & 6.6401 & 6.6417 & 6.6415 & 6.6425 & 6.6430 & 5.4954 & 0.7313 & 6.2267 \\
\hline $2001 \mathrm{Q} 3$ & 5.2140 & 6.5505 & 6.6170 & 6.6350 & 6.6403 & 6.6419 & 6.6422 & 6.6426 & 6.6428 & 5.3384 & 0.6587 & 5.9971 \\
\hline $2002 \mathrm{Q} 3$ & 5.2768 & 6.5511 & 6.6178 & 6.6353 & 6.6403 & 6.6415 & 6.6426 & 6.6421 & 6.6431 & 5.4004 & 0.6791 & 6.0795 \\
\hline 2003 Q3 & 5.2657 & 6.5435 & 6.6216 & 6.6352 & 6.6407 & 6.6410 & 6.6421 & 6.6421 & 6.6433 & 5.3827 & 0.6469 & 6.0296 \\
\hline 2004 Q3 & 5.1785 & 6.5546 & 6.6190 & 6.6369 & 6.6392 & 6.6414 & 6.6425 & 6.6426 & 6.6430 & 5.2881 & 0.5831 & 5.8713 \\
\hline $2005 \mathrm{Q} 3$ & 5.2285 & 6.5579 & 6.6226 & 6.6365 & 6.6395 & 6.6420 & 6.6420 & 6.6428 & 6.6430 & 5.3317 & 0.5732 & 5.9049 \\
\hline $2006 \mathrm{Q} 3$ & 4.7505 & 6.5723 & 6.6316 & 6.6384 & 6.6409 & 6.6419 & 6.6422 & 6.6430 & 6.6416 & 4.9095 & 0.6459 & 5.5554 \\
\hline 2007 Q3 & 4.5729 & 6.5769 & 6.6313 & 6.6382 & 6.6407 & 6.6424 & 6.6411 & 6.6430 & 6.6406 & 4.7312 & 0.5991 & 5.3303 \\
\hline 2008 Q3 & 4.4920 & 6.5852 & 6.6319 & 6.6372 & 6.6415 & 6.6422 & 6.6424 & 6.6426 & 6.6406 & 4.6444 & 0.5639 & 5.2083 \\
\hline
\end{tabular}




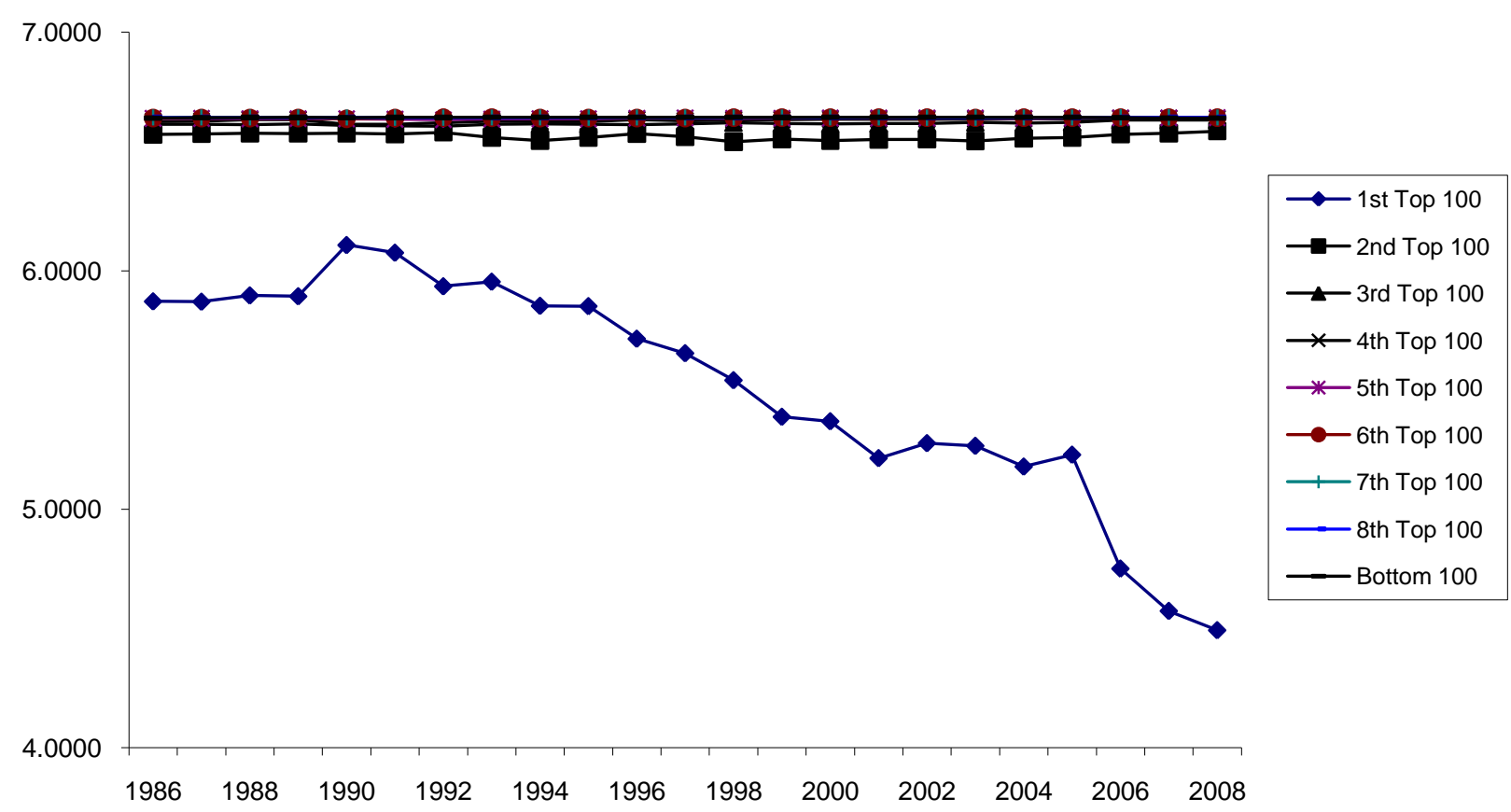

Figure 1: Entropy Coefficients Of Total Assets Of 900 BHCs (In 9 Subgroups Of 100)

The results of the entropy coefficients for the top 50 and bottom 50 BHCs total assets are given in Table 3 , Column 1, and Table 4, Column 1, respectively. The top 50 BHCs subgroup shows a significant trend toward concentration of total assets (5.13 or $91 \%$ in 1986 to 4.23 or $75 \%$ in 2008) and the bottom 50 subgroup exhibits no concentration (5.60 or $99 \%$ both in 1986 and 2008).

Applying the same methodology to the selected groups of individual assets (see Table 1), we further examine the concentration pattern of these assets for the top 50 and bottom 50 BHCs during 1986-2008. The results of the entropy coefficients of different assets are given in Tables 3 and 4, Columns 2-8. The bottom 50 BHCs' entropy coefficients changed slightly while the top 50 BHCs entropy coefficients changed significantly for all selected types of assets. Entropy coefficients of mortgage serving assets for the top 50 BHCs increased from 3.40 in 1986 to 4.24 in 1991 and thereafter declined steadily, to 2.83 in 2008. Asset IV (as defined in Table 1) and SWAP instruments exhibited a major decline in entropy coefficients in relation to all other types of assets. The most noteworthy item was the entropy coefficients of the SWAP instruments by the top 50 BHCs that changed from 3.76 or $67 \%$ in 1986 to 1.84 or $33 \%$ in 2008. 
Journal of Business \& Economics Research - July 2011

Volume 9, Number 7

\begin{tabular}{|c|c|c|c|c|c|c|c|c|}
\hline Quarter & $\begin{array}{l}\text { (1) } \\
\text { Total Assets }\end{array}$ & $\begin{array}{l}\text { (2) } \\
\text { Asset I }\end{array}$ & $\begin{array}{l}\text { (3) } \\
\text { Asset II }\end{array}$ & $\begin{array}{l}\text { (4) } \\
\text { Asset III }\end{array}$ & $\begin{array}{l}\text { (5) } \\
\text { Asset IV }\end{array}$ & $\begin{array}{l}\text { (6) } \\
\text { Asset V }\end{array}$ & $\begin{array}{l}\text { (7) } \\
\text { Asset VI }\end{array}$ & $\begin{array}{l}\text { (8) } \\
\text { SWAP }\end{array}$ \\
\hline 1986 Q3 & 5.1293 & 5.0540 & 5.0900 & 5.1296 & 4.4080 & 3.4025 & 4.7221 & 3.7685 \\
\hline 1987 Q3 & 5.1652 & 4.9190 & 5.1454 & 5.1128 & 4.5537 & 3.5515 & 4.6894 & 3.7813 \\
\hline 1988 Q3 & 5.2155 & 5.0578 & 5.1862 & 5.1801 & 4.5606 & 3.5677 & 4.8028 & 3.6891 \\
\hline 1989 Q3 & 5.2227 & 5.0523 & 5.1786 & 5.1841 & 4.4860 & 3.8475 & 4.7603 & 3.6615 \\
\hline 1990 Q3 & 5.2961 & 5.2014 & 5.2469 & 5.2061 & 4.5924 & 3.8521 & 4.8980 & 3.6838 \\
\hline 1991 Q3 & 5.2954 & 5.2575 & 5.2452 & 5.2193 & 4.4241 & 4.2351 & 4.9024 & 3.7536 \\
\hline 1992 Q3 & 5.1823 & 5.1310 & 5.1178 & 5.1056 & 4.2052 & 4.0842 & 4.7571 & 3.4878 \\
\hline 1993 Q3 & 5.2206 & 5.1621 & 5.1816 & 5.1434 & 4.2805 & 4.0304 & 4.7671 & 3.4232 \\
\hline 1994 Q3 & 5.1496 & 5.0665 & 5.1414 & 5.1200 & 4.3420 & 4.0373 & 4.8904 & 3.2680 \\
\hline 1995 Q3 & 5.1484 & 5.0618 & 5.1484 & 5.1121 & 4.3552 & 3.9694 & 4.9445 & 3.1664 \\
\hline 1996 Q3 & 5.0589 & 5.0565 & 5.0757 & 4.9889 & 4.3561 & 3.6493 & 4.8869 & 2.8604 \\
\hline 1997 Q3 & 5.0385 & 4.5308 & 5.1037 & 4.9962 & 4.3292 & 3.9751 & 4.8906 & 2.7512 \\
\hline 1998 Q3 & 4.9439 & 4.3622 & 4.9947 & 4.9348 & 4.2094 & 3.9572 & 4.7515 & 2.7935 \\
\hline 1999 Q3 & 4.8197 & 4.2798 & 4.8872 & 4.8947 & 4.1911 & 3.9025 & 4.5311 & 3.0100 \\
\hline 2000 Q3 & 4.8589 & 4.3278 & 4.8848 & 4.9573 & 4.1286 & 3.9839 & 4.6224 & 3.0139 \\
\hline $2001 \mathrm{Q} 3$ & 4.7616 & 4.2728 & 4.8146 & 4.8827 & 4.0974 & 3.8799 & 4.4481 & 2.7624 \\
\hline 2002 Q3 & 4.7980 & 4.8274 & 4.8238 & 4.8858 & 4.0433 & 3.8762 & 4.5854 & 2.8101 \\
\hline 2003 Q3 & 4.8013 & 4.7485 & 4.8427 & 4.9687 & 4.0829 & 3.8633 & 4.5517 & 2.8305 \\
\hline 2004 Q3 & 4.7492 & 4.6784 & 4.8200 & 4.9178 & 4.0601 & 3.9927 & 4.5801 & 2.9106 \\
\hline 2005 Q3 & 4.8273 & 4.7249 & 4.8819 & 4.9341 & 3.9271 & 3.8787 & 4.7016 & 2.9043 \\
\hline 2006 Q3 & 4.4282 & 4.3310 & 4.5645 & 4.7161 & 3.2199 & 3.2643 & 4.1672 & 1.9449 \\
\hline 2007 Q3 & 4.2851 & 4.0700 & 4.4234 & 4.6309 & 3.0744 & 2.9947 & 4.1591 & 1.7969 \\
\hline 2008 Q3 & 4.2258 & 3.9656 & 4.3420 & 4.5275 & 3.0745 & 2.8325 & 4.1072 & 1.8441 \\
\hline
\end{tabular}


Journal of Business \& Economics Research - July 2011

Volume 9, Number 7

\begin{tabular}{|c|c|c|c|c|c|c|c|c|}
\hline Quarter & $\begin{array}{l}\text { (1) } \\
\text { Total Assets }\end{array}$ & $\begin{array}{l}\text { (2) } \\
\text { Asset I }\end{array}$ & $\begin{array}{l}\text { (3) } \\
\text { Asset II }\end{array}$ & $\begin{array}{l}\text { (4) } \\
\text { Asset III }\end{array}$ & $\begin{array}{l}\text { (5) } \\
\text { Asset IV }\end{array}$ & $\begin{array}{l}\text { (6) } \\
\text { Asset V }\end{array}$ & $\begin{array}{l}\text { (7) } \\
\text { Asset VI }\end{array}$ & $\begin{array}{l}\text { (8) } \\
\text { SWAP }\end{array}$ \\
\hline 1986 Q3 & 5.5959 & 5.4793 & 5.5726 & 5.5267 & 4.2573 & 3.7783 & 5.4167 & 4.6065 \\
\hline 1987 Q3 & 5.5902 & 5.3915 & 5.5731 & 5.5029 & 4.3733 & 3.5351 & 5.4556 & 4.4443 \\
\hline 1988 Q3 & 5.5926 & 5.3950 & 5.5789 & 5.4908 & 4.2074 & 2.9508 & 5.4559 & 4.4735 \\
\hline 1989 Q3 & 5.5898 & 5.3692 & 5.5654 & 5.5072 & 3.9731 & 3.9220 & 5.4392 & 4.3387 \\
\hline 1990 Q3 & 5.6118 & 5.4302 & 5.5975 & 5.5049 & 4.7373 & 3.0845 & 5.1477 & 4.7359 \\
\hline 1991 Q3 & 5.6068 & 5.3477 & 5.6013 & 5.4796 & 4.6176 & 3.6135 & 5.4060 & 4.7541 \\
\hline 1992 Q3 & 5.5957 & 5.3549 & 5.5922 & 5.5051 & 4.0031 & 2.5726 & 5.4127 & 4.7238 \\
\hline 1993 Q3 & 5.5943 & 5.3621 & 5.5945 & 5.4964 & 3.7703 & 3.7321 & 5.3572 & 4.9060 \\
\hline 1994 Q3 & 5.5999 & 5.4445 & 5.5978 & 5.4978 & 3.6720 & 3.7387 & 5.4383 & 4.8729 \\
\hline 1995 Q3 & 5.5940 & 5.4805 & 5.5900 & 5.5105 & 3.6564 & 3.7224 & 5.5247 & 4.5575 \\
\hline 1996 Q3 & 5.5712 & 5.4708 & 5.5667 & 5.4924 & 3.1812 & 3.5083 & 5.4435 & 4.3088 \\
\hline 1997 Q3 & 5.5537 & 5.3782 & 5.5533 & 5.4894 & 4.2909 & 3.8300 & 5.3644 & 4.3090 \\
\hline 1998 Q3 & 5.5360 & 5.4134 & 5.5242 & 5.4892 & 3.9686 & 3.5303 & 5.2951 & 4.4007 \\
\hline 1999 Q3 & 5.5292 & 5.2950 & 5.5080 & 5.4442 & 3.2432 & 3.2847 & 5.2203 & 3.4005 \\
\hline $2000 \mathrm{Q} 3$ & 5.5164 & 5.1052 & 5.5112 & 5.4059 & 4.0973 & 3.2975 & 5.1818 & 4.4359 \\
\hline $2001 \mathrm{Q} 3$ & 5.5322 & 4.9249 & 5.5199 & 5.3988 & 4.0307 & 3.2404 & 5.1870 & 4.2486 \\
\hline $2002 \mathrm{Q} 3$ & 5.5328 & 5.3666 & 5.4917 & 5.3588 & 4.1074 & 3.5024 & 5.1863 & 4.3621 \\
\hline $2003 \mathrm{Q} 3$ & 5.5309 & 5.3047 & 5.4794 & 5.3143 & 3.6627 & 3.4149 & 5.1215 & 4.2845 \\
\hline 2004 Q3 & 5.4899 & 5.1678 & 5.4153 & 5.3390 & 3.9594 & 2.8397 & 5.1466 & 4.4353 \\
\hline 2005 Q3 & 5.4448 & 5.2354 & 5.3316 & 5.2796 & 1.9568 & 2.2994 & 5.0904 & 4.3965 \\
\hline 2006 Q3 & 5.5822 & 5.3265 & 5.5200 & 5.3087 & 3.5897 & 3.4988 & 5.4296 & 3.9625 \\
\hline 2007 Q3 & 5.5908 & 5.4665 & 5.5429 & 5.3291 & 3.3973 & 3.3205 & 5.3650 & 4.2821 \\
\hline 2008 Q3 & 5.5997 & 5.0387 & 5.5453 & 5.3441 & 3.2309 & 3.1395 & 5.4174 & 4.1630 \\
\hline
\end{tabular}




\section{CONCLUSION}

In light of the recent financial turmoil which showed that the largest bank holding companies' (i.e., Bank of America, Citicorp, etc.) systematic risk exceeded their ability to remain solvent, the result of this study has a significant policy implication (i.e., bail out the largest bank under the too-big to-fail doctrine).

Among the largest 900 BHCs in the United States, only the top 50 exhibited significant rise in total assets concentration during 1986-2008, while the remaining 850 BHCs did not exhibit any noticeable change in total assets concentration. Similarly, the concentration of the selected groups of individual assets also increased only among the 50 largest BHCs. What is more revealing is the substantial increase in usage of SWAPs as hedging instruments by the largest BHCs in the United States.

\section{ABOUT THE AUTHORS}

Dan Zhou earned her Ph.D. at the University of Memphis. Currently she is an assistant professor of finance at California State University-Bakersfield. Her research interests include market microstructure, investment and empirical finance. She has published in peer review journals and made presentations at international/national/regional conferences.

Ken Shakoori earned his Ph.D. at Clark University. Currently he is an emeritus Professor of Finance at California State University-Bakersfield. He has a long-standing interest in both applied and theoretical issues in finance. His current research interests include business valuation, banking and securities markets. He has published in peerreviewed journals and made presentations at national and international conferences.

\section{REFERENCES}

1. Attaran, Mohsen, and Martin Zewick. (1987) Entropy and Other Measures of Industrial Diversification. Quarterly Journal of Business and Economics, 26, 17-34.

2. Beck, Thorsten, Asli Demirguc-Kunt, and Ross Levine. (2005) Bank Concentration and Fragility: Impact and Mechanics. NBER Working Paper No. W11500, National Bureau of Economic Research, June 2005.

3. Berger, Allen N., Rebecca S. Demsetz, and Philip E. Strahan. (1999) The Consolidation of the Financial Services Industry: Causes, Consequences, and Implications for the Future. Journal of Banking and Finance, 23:2-4, 135-94.

4. Bergstresser, Daniel. (2004) Market concentration and loan portfolios in commercial banking. Harvard Business School; January 2004.

5. Davis, Kevin. (2007) Banking Concentration, Financial Stability and Public Policy. In The Structure and Resilience of the Financial System, pp. 255-284. Reserve Bank of Australia.

6. Demirguc-Kunt, Asli, Luc Laeven, and Ross Levine. (2004) Regulations, Market Structure, Institutions, and the Cost of Financial Intermediation. Journal of Money, Credit and Banking, 36:3-2, 593-622.

7. De Nicolo, Gianni, and Elena Loukoianova. (2007) Bank Ownership, Market Structure and Risk. IMF Working Paper No. 07/215, International Monetary Fund, September2007.

8. Schaeck, Klaus, Cihak, Martin and Wolfe Simon, Competition, Concentration and Bank Soundness: New evidence from the Micro-Level IMF, November 2006.

9. Stiroh, Kevin J., and Jennifer Poole. (2000) Explaining the Rising Concentration of Banking Assets in the 1990s. Federal Reserve Bank of New York: Current Issues in Economics and Finance, 6:9 August 2000.

10. Theil, Henry. (1967) Economics and Information Theory. Amsterdam: North-Holland.

11. Theil, Henry. (1972) Statistical Decomposition Analysis. New York, NY: American Elsevier

12. Yeyati, Eduardo Levy, and Alejandro Micco. (2007) Concentration and Foreign Penetration in Latin American Banking Sectors: Impact on Competition and Risk. Journal of Banking and Finance, 31:6, 16331647 
NOTES 